\title{
SENYAWA FENOLIK DARI KULIT BATANG Garcinia cf. cymosa DAN UJI AKTIFITAS ANTIOKSIDAN
}

\author{
Yuliar $^{1}$, Yunazar Manjang ${ }^{1}$, Syamsul A. Achmad ${ }^{2}$, dan Sanusi Ibrahim ${ }^{1}$ \\ ${ }^{1}$ Jurusan kimia, Fakultas MIPA, Universitas Andalas, Padang \\ 2 Prodi kimia, Fakutas MIPA, Institut Teknologi Bandung \\ Email : yuliarkimiauand@gmail
}

\begin{abstract}
A Phenolic compound was isolated from the bark of Garcinia cf. cymosa. Isolation methods were used are maseration, fractionation, and chromatography. Structure determination was done using spectroscopy methods including IR, H-NMR, C-NMR, DEPT, COSY, HMQC, and HMBC. The result showed that the isolated compound is (-)epicatechin. Antioxidant activity of isolated compound was determined by DPPH method. Isolated compound has antioxidant activity which has IC50 $=41,8 \mathrm{ppm}$.
\end{abstract}

Keywords : Phenolic, (-)epicatechin, Garcinia cf. cymosa, DPPH

\section{PENDAHULUAN}

Tumbuhan dari genus Garcinia kaya dengan keragaman kandungan metabolit sekunder seperti santon, benzofenon, flavonoid, steroid, terpenoid, dan turunan fenol lainnya ${ }^{[1]}$. Kandungan metabolit sekunder dari genus ini mempunyai aktifitas biologi yang sangat beragam seperti sitotoksik, antimikroba, antioksidan, dan anti $\mathrm{HIV}^{[2]}$. Beberapa senyawa fenolik yang bersifat sebagai antioksidan dari genus Garcinia adalah 1,6,7trihidroksisanton, guttiferon, dan isosantosimol ${ }^{[3]}$. Garcinia cf. cymosa merupakan salah satu spesies dari genus Garcinia yang ada di Indonesia yang menarik untuk dilakukan penelitian lebih lanjut. Penelitian ini dilakukan untuk mengisolasi senyawa fenolik, menentukan struktur, dan menguji aktifitas antioksidan.

\section{METODOLOGI PENELITIAN}

\section{Alat dan bahan}

Bahan penelitian ini berupa kulit batang tumbuhan Garcinia cf. cymosa yang diambil dari Kebun Raya Bukit Sari kabupaten Muarabungo Propinsi Jambi pada tahun 2011. Determinasi tumbuhan dlakukan di Herbarium LIPI. Bahan - bahan kimia yang digunakan untuk pemisahan dan pemurnian terdiri dari metanol, dikloro metana, etil asetat, $n$-heksana, petroleum eter, aseton, silika gel 60 G (70-230 mesh) keluaran Merck, 1,1- difenil-2-pikrilhidrazil (DPPH), pereaksi Meyer, pereaksi Lieberm Burchad, pereaksi sianoda test, $\mathrm{FeCl}_{3}$.

Alat-alat yang digunakan adalah peralatan gelas, kolom kromatografi, petridish, test tube, autoklave, jarum ose, pinset, pipet tetes, ,lampu spiritus, KLT GF $_{254} 20 \times 20 \mathrm{~cm}$ keluaran Merck, spektroskopi IR, spektroskopi UV, spektroskopi ${ }^{1} \mathrm{H}-\mathrm{NMR} 400$ $\mathrm{MHz}$ dan ${ }^{13} \mathrm{C}-\mathrm{NMR} 100 \mathrm{MHz}$, NMR $2 \mathrm{D}$, High Resolution-Mass Spectroscopy (HRTOF-MS).

\section{Prosedur Isolasi}

Serbuk kulit batang Garcinia cf.cymosa sebanyak $5 \mathrm{~kg}$ dilakukan maserasi dengan mengunakan pelarut metanol. Maserat yang diperoleh dipekatkan dengan mengunakan rotary evaporator sehingga didapatkan ekstrak pekat metanol sebanyak $647 \mathrm{~g}$. Sebanyak $200 \mathrm{~g}$ dilakukan fraksinasi dengan $n$-heksana, diklorometana, dan etil asetat. Hasil fraksinasi kemudian dipekatkan sehingga didapatkan fraksi $n$-heksana, 
diklorometana dan etil asetat berturut-turut $15,2 \mathrm{~g}, 21,4 \mathrm{~g}$, dan $38,7 \mathrm{~g}$.

Ekstrak etil asetat sebanyak $10 \mathrm{~g}$ dilakukan pemurnian dengan kromatografi kolom dengan fasa diam silika gel dan dielusi dengan $n$-heksana, diklorometana, etil asetat, dan metanol secara SGP. Hasil kromatografi kolom dimonitor dengan KLT sehingga didapatkan 21 fraksi. Fraksi 3 (F3) sebanyak $0,2 \mathrm{~g}$ dilakukan pemurnian lebih lanjut dengan metode yang sama dan didapatkan 56 fraksi. Fraksi pada nomor 25 dan 26 menunjukkan noda tunggal pada KLT sehingga kedua fraksi tersebut dikumpulkan dan didapatkan padatan berwarna putih.

Senyawa hasil isolasi kemudian diidentifikasi dengan $\mathrm{FeCl}_{3}$, dilakukan KLT berulang-ulang dengan berbagai macam pelarut dan uji titik leleh. Hasil pengujian ini mengindikasikan bahwa senyawa hasil isolasi telah murni. Penentuan struktur molekul dilakukan dengan metode spektroskopi yang meliputi IR, H-NMR, C-NMR, DEPT, COSY, HMQC, dan HMBC. Hasil pengukuran dibandingkan dengan senyawa fenolik yang sudah pernah dipublikasi.

Uji aktifitas antioksidan senyawa hasil isolasi dilakukan dengan metode $\mathrm{DPPH}^{[4]}$ yang didasarkan pada kemampuan merendam radikal DPPH. Larutan uji DPPH dibuat dengan melarutkan $9 \mathrm{mg}$ kedalam metanol sampai volumenya $450 \mathrm{~mL}$ sehingga didapatkan larutan DPPH $50 \mu \mathrm{M}$. Variasi konsentrasi uji senyawa murni dibuat dengan pengenceran larutan sehingga didapatkan konsentrasi 100, 50, 25, 12,5, 6,25, dan 3,175. Larutan DPPH $50 \mu \mathrm{M}$ sebanyak $3,8 \mathrm{~mL}$ ditambahkan larutan sampel uji sebanyak 0,2 $\mathrm{mL}$. Kemudian dihomogenkan dan dibiarkan selama 30 menit dalam ruangan gelap. Serapan diukur dengan menggunakan spektrofotometri UV-Vis dengan $\lambda$ maks $=$ $516 \mathrm{~nm}$. Sebagai kontrol positif digunakan standar asam askorbat yang diperlakukan sama seperti sampel. Aktifitas antioksidan sampel ditentukan oleh besarnya hambatan serapan radikal DPPH melalui perhitungan persentase inhibisi serapan DPPH dengan rumus sebabagai berikut:

Inhibisi $(\%)=\frac{A \text { kontrol }-A \text { sampel }}{A \text { ssorban Kontrol }} \times 100 \%$

\section{HASIL DAN PEMBAHASAN}

Senyawa hasil isolasi dari fraksi etil asetat kulit batang Garcinia cf. cymosa berupa padatan berwarna putih yang meleleh pada suhu $248-249^{\circ} \mathrm{C}$.

Pengukuran dengan spektrum inframerah menunjukan adanya pita-pita serapan untuk gugus hidroksil ( $\left.v_{\text {maks }} 3417 \mathrm{~cm}^{-1}\right)$, gugus $=\mathrm{C}-\mathrm{H}\left(v_{\text {maks }} 2962 \mathrm{~cm}^{-1}\right)$, gugus $-\mathrm{C}-\mathrm{H}\left(v_{\text {maks }}\right.$ 2920 dan $\left.2854 \mathrm{~cm}^{-1}\right)$, gugus karbonil berkonyugasi $\left(v_{\text {maks }} 1643 \mathrm{~cm}^{-1}\right)$, gugus $\mathrm{C}=\mathrm{C}$ aromatis $\left(v_{\text {maks }} 1612 ; 1558\right.$, dan $\left.1458 \mathrm{~cm}^{-1}\right)$, dan gugus $\mathrm{C}-\mathrm{O}$ eter $\left(v_{\text {maks }} 1076 \mathrm{~cm}^{-1}\right)$. Hal ini sesuai dengan senyawa fenolik yang mempunyai kerangka flavonoid.

Pengukuran dengan mengunakan alat spektroskopi HR-TOF-MS TOF ESmemberikan puncak pada 289,0948 yang menunjukan ion molekul $[\mathrm{M}-\mathrm{H}]$ dan TOF ES+ memberikan puncak pada 241,0489 yang menunjukan ion molekul $[\mathrm{M}+\mathrm{H}]$. Kedua spektrum diatas menunjukan bahwa massa molekul senyawa hasil isolasi adalah 290,1027. Setelah dikorelasikan data ini dengan ${ }^{13} \mathrm{C}$ NMR dan ${ }^{1} \mathrm{H}$ NMR, maka molekul ini diduga mempunyai rumus molekul $\mathrm{C}_{15} \mathrm{H}_{14} \mathrm{O}_{6}$ yang mempunyai massa molekul 290,0790 Dengan demikian, senyawa fenolik dengan rumus molekul $\mathrm{C}_{15} \mathrm{H}_{14} \mathrm{O}_{6}$.

Spektroskopi ${ }^{13} \mathrm{C}-\mathrm{NMR}$ dan DEPT menunjukan 15 atom karbon yang terdiri dari $7 \mathrm{CH}, 1 \mathrm{CH}_{2}$, dan $8 \mathrm{C}$ kuartener. Sinyal ke- 15 sinyal karbon itu adalah 29,6 (C-4); 66,8 (C3); 79,3 (C-2); 95,2 (C-8); 95,6 (C-6); 99,6 (C-4a); 115,1 (C-2'); 115,3 (C-5 ); 119,2 (C-6 ); 132,1 (C-1 '); 145,6 (C-3'); 145,7 (C-4); 157,0 (C-5), 157,4 (C-7), dan 157,5 (C-8a).

Spektroskopi ${ }^{1} \mathrm{H}-\mathrm{NMR}$ memberikan sinyal proton dengan pergeseran kimia 2,54-2,92 ppm $(2 \mathrm{H}$, dd, H-4 $/ / \beta) ; 4,20$ ppm $(1 \mathrm{H}, \mathrm{s}, \mathrm{H}-$ 3); 4,87 ppm ( $1 \mathrm{H}, \mathrm{s}, \mathrm{H}-2) ; 5,92 \mathrm{ppm}(1 \mathrm{H}, \mathrm{d}$, $\mathrm{J}=2,2 \mathrm{~Hz}, \mathrm{H}-8) ; 6,02 \mathrm{ppm}, 1 \mathrm{H}, \mathrm{J}=2,2 \mathrm{~Hz}$, H-6); 6,78 ppm (1H, d, J = 8,3 Hz, H-5 ); $6,83 \mathrm{ppm}(1 \mathrm{H}, \mathrm{dd} \mathrm{J}=2,2 \& 8,3 \mathrm{~Hz}, \mathrm{H}-6)$ dan 8,03 (proton fenolik). 
Spektrum ini juga memperlihatkan dua sinyal pada pergeseran kimia $\delta 6,02(1 \mathrm{H}, \mathrm{d}, \mathrm{J}=2,2$ $\mathrm{Hz})$ dan pergeseran kimia $\delta 5,91(1 \mathrm{H}, \mathrm{d}, \mathrm{J}=$ $2,2 \mathrm{~Hz}$ ), dari nilai pergeseran kimia diketahui bahwa kedua sinyal ini merupakan sinyal dari dua proton aromatis. Adanya nilai $\mathrm{J}=2,2 \mathrm{~Hz}$ menunjukkan bahwa kedua proton aromatis berorientasi meta yaitu H-6 dan H-8, dengan demikian posisi substituen dua gugus hidroksi juga berorientasi meta yaitu pada
C-5 dan C-7 pada cincin A. Analisis selanjutnya terhadap Spektrum ${ }^{1} \mathrm{H}-\mathrm{NMR}$ memperlihatkan tiga sinyal proton aromatik dengan sistem spin AMX pada $\delta 6,78(1 \mathrm{H}, \mathrm{d}$, $\left.\mathrm{J}=8,3 \mathrm{~Hz}, \mathrm{H}-5^{\prime}\right), \delta 6,83(1 \mathrm{H}, \mathrm{dd}, \mathrm{J}=2,0$ dan $8,3 \mathrm{~Hz}, \mathrm{H}-6$ '), data ini menunjukkan bahwa pada cincin $\mathrm{B}$ ada dua proton berorientasi orto ditandai dengan nilai $\mathrm{J}=8,3 \mathrm{~Hz}$ dan satu proton lainya berorientasi meta, ditandai dengan adanya nilai $\mathrm{J}=2,0 \mathrm{~Hz}$.

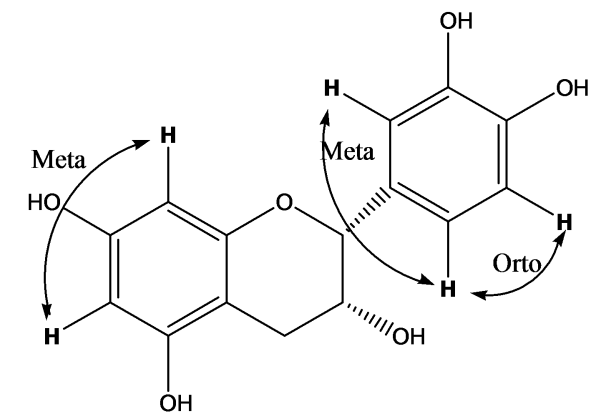

Gambar 1. Korelasi antar proton dalam senyawa (-) epikatekin.

Korelasi antar proton dalam senyawa fenolik juga didukung dengan adanya data spektrum COSY dan berdasarkan analisis tersebut di atas, mendukung bahwa senyawa hasil isolasi tersebut merupakan (-) epikatekin. Karena senyawa tersebut sudah dikenal maka dilakukan perbandingan dengan literatur ${ }^{[5]}$.

Tabel 1. Perbandingan senyawa hasil isolasi dengan (-) epikatekin yang telah diisolasi dari ekstrak metanol oleh muharni et al[5].

\begin{tabular}{|c|c|c|c|c|c|}
\hline \multirow{2}{*}{$\mathrm{C}$} & \multicolumn{2}{|c|}{${ }^{13} \mathrm{C}-\mathrm{NMR}$ (ppm) } & \multirow{2}{*}{$\mathrm{H}$} & \multicolumn{2}{|c|}{${ }^{1} \mathrm{H}-\mathrm{NMR}$ (ppm) } \\
\hline & Senyawa & (-) epikatekin & & Senyawa & (-) epikatekin \\
\hline 2 & 79,3 & 80,0 & 2 & 4,87 & 4,82 \\
\hline 3 & 66,8 & 67,6 & 3 & 4,20 & 4,18 \\
\hline 4 & 29,6 & 29,4 & $4 \alpha$ & 2,54 & 2,74 \\
\hline & & & $4 \beta$ & 2,92 & 2,85 \\
\hline $4 a$ & 99,6 & 100,0 & & & \\
\hline 5 & 157,0 & 157,5 & & & \\
\hline 6 & 95,6 & 96,0 & 6 & 6,02 & 5,94 \\
\hline 7 & 157,4 & 157,8 & & & \\
\hline 8 & 95,2 & 96,4 & 8 & 5,92 & 5,91 \\
\hline $8 \mathrm{a}$ & 157,5 & 158,1 & & & \\
\hline $1^{\prime}$ & 132,1 & 132,4 & & & \\
\hline 2 & 115,1 & 115,4 & 2 & 7,05 & 6,97 \\
\hline 3 & 145,6 & 146,1 & & & \\
\hline 4 & 145,7 & 145,9 & & & \\
\hline 5 & 115,3 & 116,0 & 5 & 6,78 & 6,75 \\
\hline 6 & 119,2 & 119,5 & 6 & 6,83 & 6,78 \\
\hline
\end{tabular}


Spektrum HMBC memberikan informasi tentang letak proton terhadap karbon mempelajari korelasi yang terjadi sepanjang dua atau tiga ikatan antara proton dan karbon sehingga dapat diketahui pola substitusi struktur flavonoid hasil isolasi.

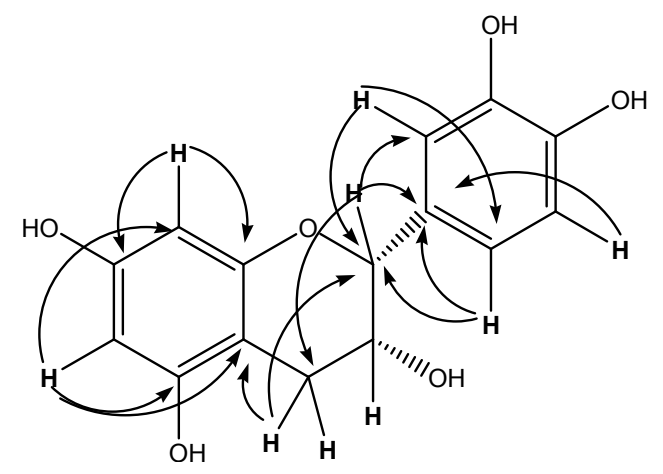

Gambar 2. Korelasi dari HMBC senyawa hasil isolasi.

Uji aktifitas antioksidan dengan peredaman radilkal DPPH dilakukan dengan mengukur absorbansi jumlah radikal DPPH sisa dengan alat spektroskopi sinar tampak pada $\lambda_{\text {maks }} 516$ nm. Kemampuan suatu senyawa dalam merendam radikal DPPH pada konsentrasi tertentu, dihitung melalui \% inhibisi. Minami et al (1994) $)^{[6]}$. menggolongkan kekuatan senyawa antioksidan berdasarkan nilai $\mathrm{IC}_{50}$. Suatu senyawa dikelompokan menjadi kategori sangat aktif, aktif dan tidak aktif jika nilai $\mathrm{IC}_{50}$ berturut-turut : $<10 ;<100$, dan $>$ 100. Grafik hubungan konsentrasi ekstrak uji dengan $\%$ inhibisi, menggunakan metode DPPH tertera pada Gambar 3

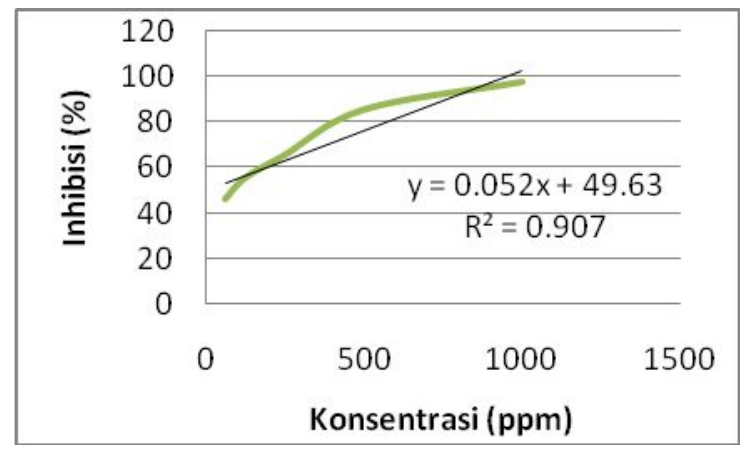

Gambar 3. Grafik uji antioksidan senyawa hasil isolasi.

Senyawa hasil isolasi mempunyai nilai $\mathrm{IC}_{50}=$ 41,8 ppm, oleh karena itu tergolong aktif terhadap uji antioksidan karena nilai $\mathrm{IC}_{50}<$ 100 ppm. Hasil ini sesuai dengan Molyneux ${ }^{[7]}$ yang menyebutkan bahwa sifat antioksidan lebih baik bila nilai $\mathrm{IC}_{50}$ lebih kecil. Suatu zat dikatakan memiliki sifat antioksidan bila nilai $\mathrm{IC}_{50}$ yang dihasilkan kurang dari 200 ppm.
Senyawa hasil isolasi dari fraksi etil asetat kulit batang Garcinia cf. cymosa ini adalah (-) epikatekin. Aktifitas antioksidannya setelah diuji dengan menggunakan metode DPPH menunjukan aktifitas yang tinggi yaitu $\mathrm{IC}_{50}=41,8 \mathrm{ppm}$. 
Terima kasih disampaikan disampaikan kepada Dr. Eng. Morina adfa, M.Si yang telah membantu pengukuran spektrum NMR, herbarium LIPI yang telah membantu penentuan spesies tumbuhan, dan bapak M. Subkhan Dinas Kehutanan Prop. Jambi yang telah membantu dalam pengambilan sampel.

\section{Daftar Pustaka}

1. G. S. Joseph, G. K. Jayapraksa, and A. T. Selvi, Antiflatoxigenic and antioxidant activities of Garcinia Extract. Int. Journal of Food Microbology., 101: 153-160, (2005).

2. Lannang, A. M. Komguem, J., F. N. Ngninzeko, J. Tangmoua, Two xanthone from the steam bark of Garcinia polyantha Oliv. Phytochemistry., 60: 2351-2355, (2005).
3. Elfita, Santon dan benzofenon dari tubuhan kandis gajah (Garcinia griffithii) dan aktifitas aktioksidannya. Disertasi Universitas Padjajaran, 2008.

4. Zhang, N. P. Seeram, R. Lee, Isolation and identification of strawberry phenolics with antioxidant and cancer cell antipoliferative, Agric. Food chem., 56(3): 670-675.

5. Muharni, Phenolic compound from the stem bark of manggis hutan (Garcinia bancana) and their antioxidant activity, Indo. J. Chem. 9 (20): 321-327, (2009).

6. H. Minami, K. Hamaguchi, and M. Kubo, a benzophenone and a xanthone from garcinia subelliptica, Phytochemistry., 49(6): 1783-1785, (1998).

7. P. Molyneux P. The use of the stable free radicals diphenylpicrylhydrazyl (DPPH) for estimating antioxidant activity, Songklanakarin J. Sci. Technol., 26(2): 211219, (2004). 